\title{
Differentiation of Dictyostelium discoideum Cells in Suspension Culture
}

\author{
By KOJI OKAMOTO \\ Department of Botany, Faculty of Science, Kyoto University, Kyoto 606, Japan
}

(Received 17 November 1980; revised 10 April 1981)

Differentiation of Dictyostelium discoideum cells in suspension culture is reported, using a medium containing glucose, albumin, cyclic AMP, EDTA and streptomycin in a phosphate buffer. Production of UDPgalactose:polysaccharide transferase, an enzyme specifically present in prespore cells, and the formation of prespore-specific antigens in more than $60 \%$ of the cells, are demonstrated. Differentiation in this medium differs from that previously reported with other suspension systems in that (a) cells form only small, amorphous agglomerates, (b) there is an absolute requirement for cyclic AMP and (c) prior formation of loose cell mounds on a solid substratum is essential for subsequent differentiation in this medium. This last requirement indicates that the differentiation process, giving rise to the prespore-specific enzyme and antigen, can be resolved into two distinct stages, one requiring cell contact on a solid substratum and the other proceeding in small agglomerates incubated in the medium. This medium may be useful for elucidating the role of cyclic AMP and cell contact in slime mould development.

\section{INTRODUCTION}

The cellular slime mould Dictyostelium discoideum has a unique differentiation pattern in that, upon starvation, cells which have multiplied as single amoebae gather to form a multicellular complex and differentiation into two cell types (prespore and prestalk) normally occurs only in the cell mass. The latter characteristic suggests that cellular interaction plays an important role in the differentiation of this organism. The question then arises as to what sort of signals are generated in such an organized multicellular system for triggering differentiation.

Previous studies from this laboratory (Takeuchi \& Sakai, 1971; Okamoto \& Takeuchi, 1976; Oohata, 1976; Okamoto, 1979; Uchiyama et al., 1979) and other laboratories (Newell et al., 1971; Firtel \& Bonner, 1972; Darmon, 1976; Alton \& Lodish, 1977; Landfear \& Lodish, 1980) have revealed that, when multicellular complexes are disaggregated, a number of biochemical changes are induced and the cells undergo dedifferentiation. Some of the changes were shown to be blocked by addition of cyclic AMP (Takeuchi \& Sakai, 1971; Takemoto et al., 1978; Landfear \& Lodish, 1980), indicating that in certain respects cyclic AMP reverses the effect of loss of cell contact and promotes differentiation. That the synthesis of many of the post-aggregative enzymes, which appear after aggregate formation, are dependent on cyclic AMP was also shown by other workers (Rickenberg et al., 1977; Town \& Gross, 1978; Kay, 1979; Kay et al., 1979; Landfear \& Lodish, 1980). In contrast, cyclic AMP has almost no protecting effect on the disaggregation-induced inactivation of UDPgalactose:mucopolysaccharide galactosyltransferase (EC 2.4.1.74) (Okamoto \& Takeuchi, 1976), a prespore-specific post-aggregative enzyme. With the EDTA-containing medium which we use for disaggregation studies, induction or maintenance of this enzyme has never been achieved with disaggregated slug cells. Since this enzyme is found only in prespore cells (Newell et al., 1969; Oohata \& Takeuchi, 1977), its activity in the cell can be 
taken as an index of differentiation of prespore cells. During the course of a study of the mechanism of disaggregation-induced decay of UDPgalactose transferase activity, I found (unpublished) that this decay was greatly suppressed by the presence of glucose and albumin. On the basis of these findings, it was expected that if glucose, albumin and cyclic AMP were provided in the medium the cells undergoing normal differentiation might be able to continue their programme of differentiation even after disaggregation.

The present paper describes experiments demonstrating prespore formation in such a medium, starting from cells obtained by disaggregation of loose cell mounds. It was revealed that this system has several unique features as compared to the previously reported submerged culture systems and may provide a useful means of elucidating the role of cell contact and cyclic AMP in slime mould differentiation.

\section{METHODS}

Dictyostelium discoideum NC-4 was grown by gyratory shaking at $21^{\circ} \mathrm{C}$ in $20 \mathrm{~mm}$-sodium phosphate/ potassium phosphate buffer ( $\mathrm{pH} \mathrm{6.0)}$ ) containing $2.3 \mathrm{mg} \mathrm{ml}^{-1}$ of lyophilized Escherichia coli $\mathrm{B} / \mathrm{r}$ cells. Under these conditions, the doubling time was $3-3.5 \mathrm{~h}$ and the maximum density was $1 \times 10^{7}$ cells $\mathrm{ml}^{-1}$. When the cell density reached 2-6 $\times 10^{6} \mathrm{ml}^{-1}$, amoebae were collected in $\mathrm{KCl} /$ phosphate buffer $(20 \mathrm{mM}-\mathrm{KCl}$ and $40 \mathrm{mM}$-phosphate buffer, pH 6.4) and spread on Millipore membranes (HAWP), wetted with the same solution, at a density of $4 \times$ $10^{6}$ cells $\mathrm{cm}^{-2}$. After incubation at $21^{\circ} \mathrm{C}$ for the indicated periods of time, cells were collected and disaggregated mechanically in $\mathrm{KCl}$ /phosphate buffer with $1 \mathrm{mM}$-EDTA added. Cells were then suspended in GAC medium (see below), with different components omitted where indicated, at a density of $1 \times 10^{7} \mathrm{cells} \mathrm{m}^{-1}$ and shaken reciprocally at 150 strokes $\min ^{-1}$ at $22-25{ }^{\circ} \mathrm{C}$. GAC medium contained $5 \%(\mathrm{w} / \mathrm{v})$ glucose, $2 \%(\mathrm{w} / \mathrm{v})$ albumin (from bovine serum, fraction V; the product of either Sigma or Armour Pharmaceuticals Co., Phoenix, Arizona, U.S.A.), 1 mM-cyclic AMP, 2 mM-EDTA and $100 \mu \mathrm{g}$ streptomycin $\mathrm{ml}^{-1}$ in $20 \mathrm{mM}$-phosphate buffer, $\mathrm{pH} 6.0$.

At the indicated times, $100 \mu \mathrm{l}$ samples were taken, diluted in $1 \mathrm{ml}$ phosphate buffer and the cells were pelleted by centrifugation. The pellets were kept frozen until use. UDPgalactose transferase activity (EC 2.4.1.74) was assayed essentially as described previously (Okamoto \& Takeuchi, 1976) except that a larger amount of acid mucopolysaccharide was used, the concentration of UDP $\left[\mathrm{U}-{ }^{14} \mathrm{C}\right]$ galactose was doubled and $5 \mathrm{mM}$-spermine was included in the incubation mixture. Staining of prespore cells was done as follows. Agglomerates were dissociated by incubation in $10 \mathrm{~mm}-\mathrm{NaN}_{3}$ for $10 \mathrm{~min}$ and vigorous vortexing, and the cells were washed and treated with $70 \%$ chilled methanol. A few drops of the cell suspension were placed on a cover-slip and allowed to dry in the cold, and the cells were stained with fluorescein-conjugated rabbit immunoglobulin, fractionated by the method of Strauss $e t$ al. (1960) from the antiserum prepared against Dictyostelium mucoroides spores (Takeuchi, 1963).

\section{RESULTS}

When washed amoebae of $D$. discoideum were deposited on a Millipore membrane and incubated for $9.5 \mathrm{~h}$ at $21^{\circ} \mathrm{C}$, cells formed discrete mounds. Tips had not formed by this time and UDPgalactose transferase activity was still very low. At this stage, cells were mechanically dissociated from the mounds, suspended in GAC medium and shaken at $25^{\circ} \mathrm{C}$. The transferase activity began to increase after a few hours of shaking, reached a maximum at about $15 \mathrm{~h}$ in this experiment (Fig. 1), and began to decrease after $25 \mathrm{~h}$ shaking. About $60 \%$ of the cells accumulated spore-specific antigen during this period (Fig. 1). The cells stained with fluorescein-conjugated antispore globulin contained prespore vacuoles clearly observable under a fluorescence microscope, just like the prespore cells present in a slug. The intensities of fluorescence (i.e. the amount of spore-specific antigen) in individual stained cells were also comparable with those in stained slug cells. From these results, it was concluded that prespore cells were formed in this shaking system.

During shaking, cells in either GAC medium or phosphate/EDTA medium formed agglomerates, but these were not as large as those formed in $\mathrm{Mg}^{2+}$-containing medium (Fig. 2). Although the size distribution of agglomerates in GAC medium varied considerably depending on the experimental conditions, possibly because of the susceptibility of agglomerates to shearing force, the level of transferase activity attainable was usually not 


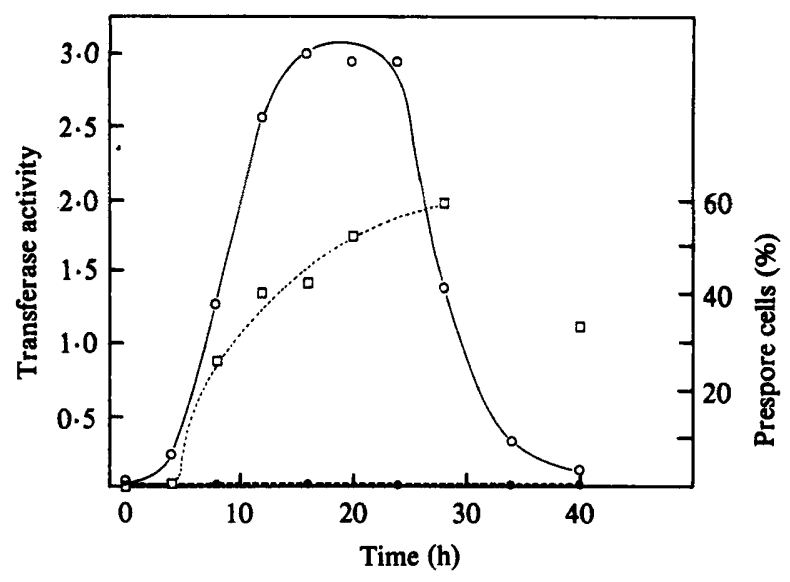

Fig. 1. Requirement for glucose, albumin and cyclic AMP for induction of UDPgalactose transferase and prespore formation in GAC medium. Washed cells of $D$. discoideum NC-4 were spread on Millipore membranes. After $9.5 \mathrm{~h}$ incubation at $21^{\circ} \mathrm{C}$, the cell mounds formed were disaggregated, suspended in GAC medium and shaken at $25^{\circ} \mathrm{C}$ (defined as time 0). At intervals, samples of the suspension were taken for measurements of UDPgalactose transferase activity and of the proportion of prespore cells. Transferase activity [expressed as pmol galactose transferred $\left(10^{7} \text { cells }\right)^{-1} \mathrm{~min}^{-1}$ ] in GAC medium (O) and in GAC medium minus cyclic AMP (O). Proportion of prespore cells in GAC medium ( $\square)$.
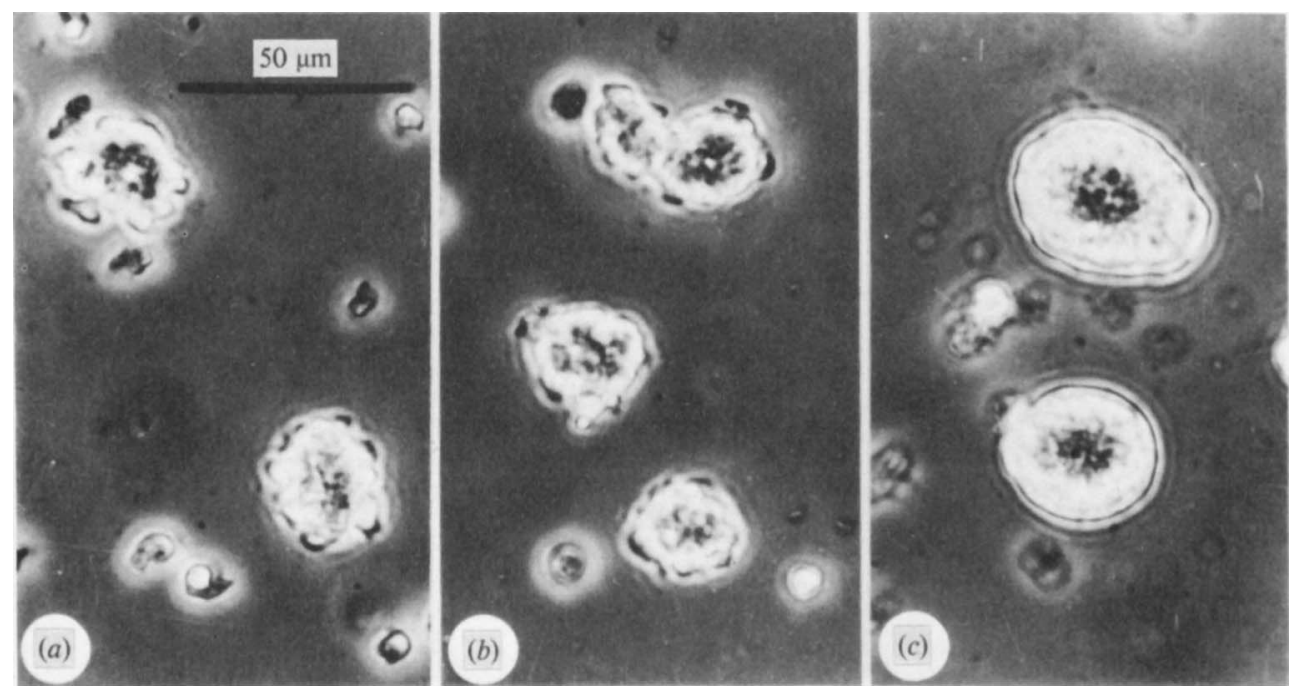

Fig. 2. Micrographs showing agglomerate formation during shaking under different conditions. Washed cells of $D$. discoideum NC-4 were spread on Millipore membranes and incubated for $10 \mathrm{~h}$. Cells were then collected, disaggregated, resuspended at a density of $1 \times 10^{7}$ cells ml-1 in the medium indicated and shaken (150 strokes $\min ^{-1}$ ) for $10.5 \mathrm{~h}$. Media: (a) GAC medium; (b) phosphate buffer (20 mM, pH 6) containing EDTA ( $2 \mathrm{mM}$ ) and cyclic AMP (1 mM); (c) phosphate buffer (20 mM, pH 6) containing $\mathrm{MgSO}_{4}(2 \mathrm{mM})$ and cyclic AMP (1 mM), in this case using a siliconized flask.

very much affected by the size of agglomerates, as long as cells were in contact. In the agglomerates formed in GAC medium, cell boundaries could not be seen by phase-contrast microscopy. However, the treatment with $10 \mathrm{~mm}-\mathrm{NaN}_{3}$ loosened the cell masses, thus rendering individual cells clearly observable. Agglomerates did not appear to be covered by a slime sheath, since (a) the surface was not smooth, (b) extruded pseudopods were often seen 


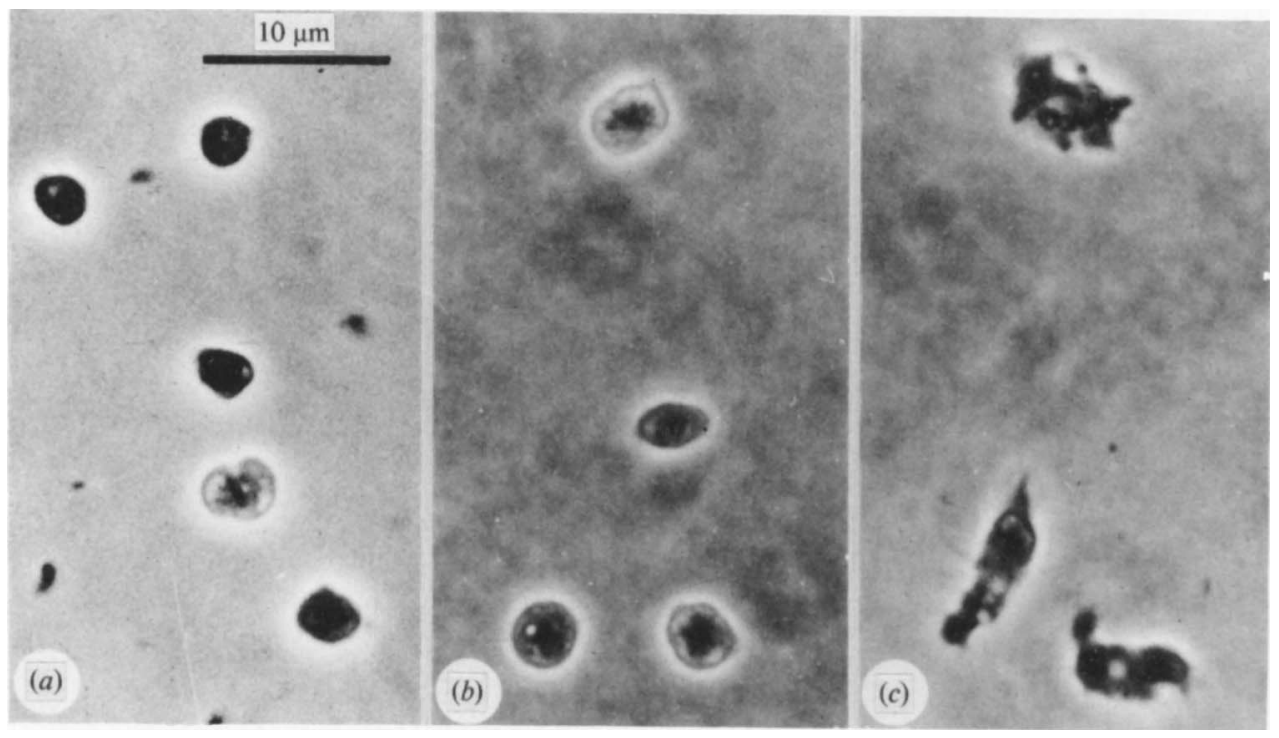

Fig. 3. Micrographs of cells shaken in GAC medium $(a)$ and of prespore $(b)$ and prestalk $(c)$ cells isolated from slugs. (a) Cells disaggregated from $9.5 \mathrm{~h}$ mounds were shaken in GAC medium for $20 \mathrm{~h}$, washed with phosphate buffer $(20 \mathrm{mM}, \mathrm{pH} 7 \cdot 1)$, placed on a cover-slip and incubated for about $30 \mathrm{~min}$. $(b, c)$ Prespore $(b)$ and prestalk $(c)$ cells were prepared by separation by Urografin gradient centrifugation of cells disaggregated from slugs, according to the method of Tasaka \& Takeuchi (1979).

\section{Table 1. Effects of glucose, albumin and $\mathrm{NH}_{4} \mathrm{Cl}$ on cell differentiation in suspension culture}

Cell mounds of $D$. discoideum NC-4 were disaggregated at $10 \mathrm{~h}$ after deposition on Millipore filters, and the cells were shaken in the medium indicated. At 10 and $19 \mathrm{~h}$ after the start of shaking, samples were taken for assay of UDPgalactose transferase activity.

\begin{tabular}{|c|c|c|}
\hline \multirow[b]{2}{*}{ Medium } & \multicolumn{2}{|c|}{$\begin{array}{c}\text { Transferase activity } \\
\text { [pmol galactose transferred } \\
\left(10^{7} \text { cells }\right)^{-1} \mathrm{~min}^{-1} \text { ] }\end{array}$} \\
\hline & $10 \mathrm{~h}$ & $19 \mathrm{~h}$ \\
\hline $\begin{array}{l}\text { Complete GAC } \\
\text { - albumin } \\
\text { - glucose } \\
\text { - glucose }- \text { albumin } \\
\text { - glucose }+\mathrm{NH}_{4} \mathrm{Cl}(140 \mathrm{~mm})\end{array}$ & $\begin{array}{l}6 \cdot 38 \\
0.91 \\
3 \cdot 35 \\
0 \cdot 04 \\
2 \cdot 05\end{array}$ & $\begin{array}{l}7.60 \\
0 \cdot 18 \\
0 \cdot 81 \\
0 \cdot 01 \\
4 \cdot 01\end{array}$ \\
\hline
\end{tabular}

and (c) after standing under a cover-glass, cells crawled out of agglomerates. In $\mathrm{Mg}^{2+}$-containing medium, disaggregated cells formed large agglomerates within $1 \mathrm{~h}$ of shaking under the conditions usually employed for differentiation. In GAC medium, agglomerate formation occurred at a much slower rate; small agglomerates appeared in 4-5 $\mathrm{h}$ and increased in size until about $10 \mathrm{~h}$. After prolonged shaking (about $20 \mathrm{~h}$ ) the agglomerates tended to dissociate. Unlike the culture in $\mathbf{M g}^{2+}$-containing medium, no cells stuck to the wall throughout the shaking period even without siliconization of the vessel. Essentially all cells had an appearance similar to that of prespore cells isolated from slugs (Fig. 3). No spore formation was seen under these conditions even after prolonged shaking. Prespore vacuoles disappeared very slowly after transferase activity reached its peak.

If cyclic AMP was omitted from GAC medium, no increase in transferase activity was observed (Fig. 1). If albumin alone was omitted, only about $5 \%$ of the transferase activity was induced, while the omission of glucose alone resulted in accumulation of considerable 


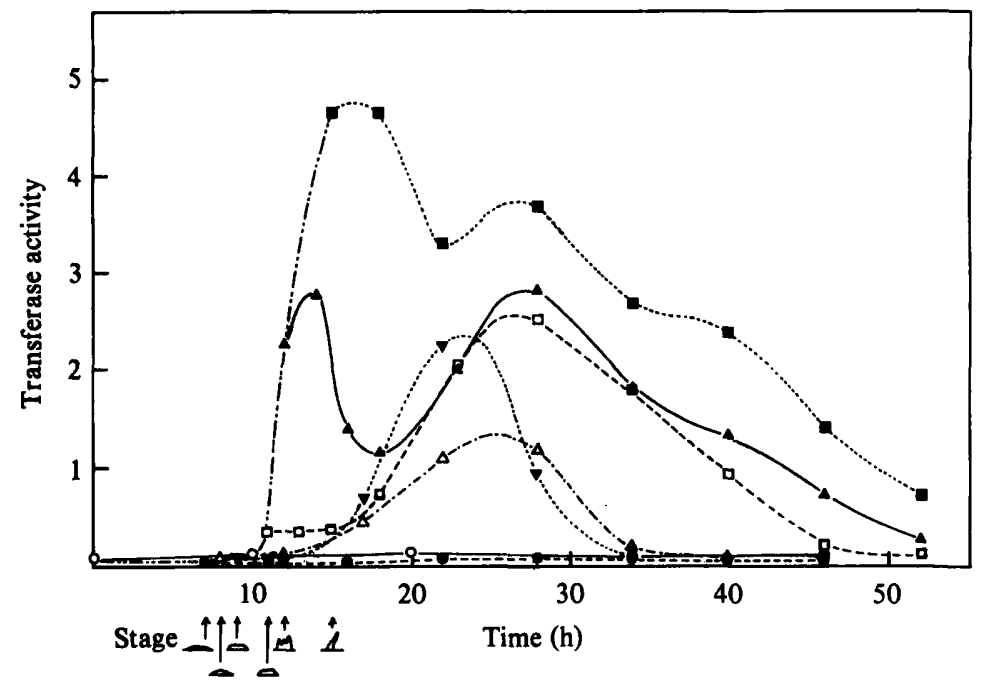

Fig. 4. Requirement for prior formation of aggregates on a Millipore membrane for induction of UDPgalactose transferase in GAC medium. Washed cells of $D$. discoideum were spread and incubated on Millipore membranes at time 0 . At the indicated times, cells were collected from the membranes, disaggregated, suspended in GAC medium and shaken at $25^{\circ} \mathrm{C}$. Samples were taken at intervals and assayed for UDPgalactose transferase activity. Transferase activity [expressed as pmol galactose transferred $\left.\left(10^{7} \text { cells }\right)^{-1} \mathrm{~min}^{-1}\right]$ of the cells collected from Millipore membranes at $0 \mathrm{~h}(\mathrm{O}), 7 \mathrm{~h}(\mathrm{O}), 8 \mathrm{~h}$ $(\triangle), 9 \mathrm{~h}(\nabla), 11 \mathrm{~h}(\square), 12 \mathrm{~h}(\Delta)$ and $15 \mathrm{~h}(\square)$. Transferase activity of cells on the Millipore membrane $(-\cdots-)$.

transferase activity during the first $10 \mathrm{~h}$ shaking but a marked decrease during the next $10 \mathrm{~h}$ (Table 1). In this case, the formation of quite large agglomerates was seen. Omission of both glucose and albumin from the medium resulted in complete loss of the ability to accumulate transferase activity (Table 1). Studies with combinations of various concentrations of each component in the medium revealed that the concentrations in GAC medium were near optimal for cells to undergo differentiation (data not shown). In this shaking system, glucose could be replaced, with almost equal efficiency, by other sugars such as maltose, lactose or trehalose at the same molarity $(280 \mathrm{mM})$. Mannitol, galactose or sucrose were, however, only partially effective. Among monovalent cations $(140 \mathrm{mM})$ tested, only $\mathrm{NH}_{4}{ }^{+}$partially replaced sugars (Table 1). Egg white albumin (crystalline, Sigma) could be substituted for bovine serum albumin. All other proteins $(2 \%, \mathrm{w} / \mathrm{v})$ tested were almost completely or totally without effect: these included $\gamma$ globulin (from bovine plasma), casein, gelatin, histone, lysozyme, haemoglobin and trypsin. For replacement of cyclic AMP, other nucleotides were tested at $1 \mathrm{mM}$ : cyclic GMP, dibutyryl cyclic AMP, ATP, ADP and AMP were essentially without effect.

In the above experiments, cells disaggregated from 9.5-10 h mounds were used. Next, cells collected at various times after deposition on a Millipore membrane were examined for their ability to differentiate in GAC medium. Cells collected after less than $7 \mathrm{~h}$ on a Millipore membrane were completely unable to increase transferase activity, while cells disaggregated after $8 \mathrm{~h}$ could do so to a considerable extent (Fig. 4). After $12 \mathrm{~h}$ incubation on a Millipore membrane, the activity sharply increased in the multicellular complexes, in accord with the previous report (Sussman \& Osborn, 1964). When the complexes were disaggregated at such stages and shaken in GAC medium, the enzyme activity first dropped but subsequently increased to a peak. In a separate experiment, vegetative cells were starved by shaking in phosphate buffer $(20 \mathrm{mM}, \mathrm{pH} 6.0)$ for 7 or $11 \mathrm{~h}$, during which time the cells acquired full competence for aggregation, as indicated morphologically and also as measured by cell-bound phosphodiesterase activity. These cells were found to lack almost completely the 
ability to accumulate transferase activity during subsequent shaking in GAC medium. Furthermore, even cells starved in the presence of cyclic AMP (1 mM) for 8 or $11 \mathrm{~h}$ in suspension could not differentiate in GAC medium (data not shown).

\section{DISCUSSION}

Differentiation of $D$. discoideum NC-4 cells has now been shown to proceed in suspension in GAC medium, which contains EDTA. So far, many workers have demonstrated differentiation of slime mould cells in suspension cultures in roller tubes (Sternfeld \& Bonner, 1977; Takeuchi et al., 1977) or by gyratory shaking (Garrod \& Forman, 1977; Kay, 1979; Kay et al., 1979; Sternfeld \& David, 1979), where transferase activity was shown to be induced (Takeuchi et al., 1978; Kay, 1979), giving rise to prespore cells. However, it should be noted that the media used in those experiments did not contain EDTA. In these cases, cells form quite large agglomerates, which are usually spherical, and in many cases they are eventually covered with a slime sheath. Such an agglomerate can thus be regarded as an independent multicellular matrix having its own regulatory system, just like a slug formed on solid substratum. In contrast to this, in EDTA-containing phosphate buffer, we have never been able to demonstrate cell differentiation in suspension even when aggregation-competent cells were used, although cells formed agglomerates (Fig. $2 b$, see also Okamoto \& Takeuchi, 1976). Therefore, agglomerate formation by itself is not sufficient for causing differentiation. EDTA presumably interferes with differentiation by blocking essential reactions through chelating certain cations. Only under the conditions where large cell-mass formation was allowed without shaking did spore differentiation occur in the presence of EDTA (Gerisch, 1961; Loomis \& Sussman, 1966). The present experiments demonstrate that the addition of glucose, albumin and cyclic AMP to EDTA-containing media permits cells to undergo differentiation under shaking conditions without allowing the formation of very large agglomerates, though at a slower rate than on a solid substratum. The reason for overcoming the EDTA effect under these conditions is completely unknown. In the previous submerged culture systems (Kay, 1979; Kay et al., 1979), cell differentiation proceeded even without added cyclic AMP and the addition of exogenous cyclic AMP only stimulated this process. In clear contrast to this, cyclic AMP is absolutely required in the GAC system for cell differentiation. The requirement for prior cell contact also makes this system distinct from others. These results indicate that the differentiation inducing ability of GAC medium is not simply a result of blockage of EDTA by metal ions carried over with albumin.

Among many kinds of proteins tested, only albumin was competent in supporting cell differentiation. Although the exact reason for this albumin-specific effect is not clear, it may be related to the fact that many biological materials are efficiently stabilized only by albumin (Mitsui \& Mizuno, 1969; Goto \& Mizushima, 1978). It should also be pointed out that $\mathrm{NH}_{4}{ }^{+}$ at high concentrations could partially substitute the effect of glucose in GAC medium. This is in agreement with the previous finding (Takeuchi et al., 1978) that $\mathrm{NH}_{4}^{+}$greatly inhibited disaggregation-induced decay of transferase activity. $\mathrm{NH}_{4}{ }^{+}$is also one of the requirements for spore formation (Wilcox \& Sussman, 1978; Sternfeld \& David, 1979), though at much lower concentrations. However, as to the non-ionic form of ammonia, an inhibitory effect on differentiation in submerged culture has been reported (Kay, 1979). An unexpected observation with respect to nucleotide specificity in the GAC system was that dibutyryl cyclic AMP was almost completely ineffective in the induction of prespore cells. This is in contrast with previous cases (Klein, 1975; Takemoto et al., 1978; Ishida, 1980), where this nucleotide always showed at least some effect on $D$. discoideum when substituted for cyclic AMP.

One important fact emerged from the present experiments: in order for cells to differentiate into prespore cells in GAC medium, they had to be incubated on solid substratum until the time of discrete mound formation. Shaking in suspension to make cells aggregationcompetent was not sufficient to cause differentiation. It is thus probable that cellular 
interaction in mounds for a certain period of time is a prerequisite for later differentiation. The requirement for both cyclic AMP and cell contact in prespore formation has recently been shown by the use of a cellophane overlay method (Town et al., 1976; Kay et al., 1978). Our present results further revealed that, once the initiation of differentiation is triggered through cell contact in the loose cell mounds, the cells can proceed to differentiate without sustained contact of that kind, if transferred into GAC medium. In this respect, our results agree in principle with the report (Wilcox \& Sussman, 1978) that disaggregated cells of a mutant strain differentiate only after prior cell contact. The requirement for cyclic AMP was, however, not demonstrated in their work.

Our preliminary experiments on the activity changes of several enzymes indicate that in GAC medium no increase in activities of UDPglucose pyrophosphorylase and trehalosephosphate synthetase occurred during prespore formation, a result which is completely at variance with the normal developmental course. Further studies on the changes occurring during mound formation and during shaking in GAC medium are now in progress. Elucidation of the role of cyclic AMP and cell contact in slime mould differentiation might be facilitated by the use of this system.

I thank Dr I. Takeuchi for his valuable advice and discussions during the work. Thanks are also due to Dr M. Tasaka for providing the micrographs of prespore and prestalk cells.

\section{REFERENCES}

Alton, T. H. \& Lodish, H. F. (1977). Synthesis of developmentally regulated proteins in Dictyostelium discoideum which are dependent on continued cell-cell interaction. Developmental Biology 60, 207-216.

Darmon, M. (1976). Rôle possible des contacts cellulaires dans l'arrêt d'un programme de différenciation chez Dictyostelium discoideum. Comptes rendus hebdomadaires des séances de l'Académie des Sciences 282, 1893-1896.

FirTEL, R. A. \& BonNER, J. (1972). Developmental control of alpha 1-4 glucan phosphorylase in the cellular slime mold Dictyostelium discoideum. Developmental Biology 29, 85-103.

Garrod, D. R. \& Forman, D. (1977). Pattern formation in the absence of polarity in Dictyostelium discoideum. Nature, London 265, 144-146.

GERISCH, G. (1961). Zellfunktionen und Zellfunktionswechsel in der Entwicklung von Dictyostelium discoideum. Wilhelm Roux Archiv für Entwicklungsmechanik der Organismen 153, 158167.

Goto, K. \& Mizushima, S. (1978). Removal by bovine serum albumin of fatty acids from membrane vesicles and its effect on proline transport activity in Escherichia coli. Journal of Biochemistry 84, 251258.

IsHIDA, S. (1980). The effects of cyclic AMP on differentiation of a mutant Dictyostelium discoideum capable of developing without morphogenesis. Development, Growth and Differentiation 22, 781788.

KAY, R. R. (1979). Gene expression in Dictyostelium discoideum: mutually antagonistic roles of cyclicAMP and ammonia. Journal of Embryology and Experimental Morphology 52, 171-182.

KAY, R. R., Garrod, D. \& Tilly, R. (1978).
Requirement of cell differentiation in Dictyostelium discoideum. Nature, London 271, 58-60.

KAY, R. R., Town, C. D. \& Gross, J. D. (1979). Cell differentiation in Dictyostelium discoideum. Differentiation 13, 7-14.

KLEIN, C. (1975). Induction of phosphodiesterase by cyclic adenosine $3^{\prime}: 5^{\prime}$-monophosphate in differentiating Dictyostelium discoideum amoebae. Journal of Biological Chemistry 250, 7134-7138.

LANDFEAR, S. M. \& LoDISH, H. F. (1980). A role for cyclic AMP in expression of developmentally regulated genes in Dictyostelium discoideum. Proceedings of the National Academy of Sciences of the United States of America 77, 1044-1048.

Loomis, W. F. \& Sussman, M. (1966). Commitment to the synthesis of a specific enzyme during slime mold development. Journal of Molecular Biology 22, 401-404.

Mrrsui, E. \& Mizuno, D. (1969). Stabilization of colicin E2 by bovine serum albumin. Journal of Bacteriology 100, 1136-1137.

Newell, P. C., Ellingson, J. S. \& Sussman, M. (1969). Synchrony of enzyme accumulation in a population of differentiating slime mold cells. Biochimica et biophysica acta 177, 610-614.

Newell, P. C., Longlands, M. \& Sussman, M. (1971). Control of enzyme synthesis by cellular interaction during development of the cellular slime mold Dictyostelium discoideum. Journal of Molecular Biology 58, 541-554.

ОКАмото, K. (1979). Induction of cyclic AMP phosphodiesterase by disaggregation of the multicellular complexes of Dictyostelium discoideum. European Journal of Biochemistry 93, 221-227.

OKAмото, K. \& TAKeUCHI, I. (1976). Changes in activities of two developmentally regulated enzymes induced by disaggregation of the pseudoplasmodia 
of Dictyostelium discoideum. Biochemical and Biophysical Research Communications 72, 739-746.

OohatA, A. (1976). Changes in $\beta$-galactosidase activity during differentiation and dedifferentiation in Dictyostelium discoideum. Botanical Magazine, Tokyo 89, 115-122.

OOHATA, A. \& TAKEUCH, I. (1977). Separation and biochemical characterization of the two cell types present in the pseudoplasmodium of Dictyostelium mucoroides. Journal of Cell Science 24, 1-9.

RickenberG, H. V., TiHON, C. \& GüZEL, Ö. (1977) The effect of pulses of $3^{\prime}: 5^{\prime}$ cyclic adenosine monophosphate on enzyme formation in nonaggregated amoebae of Dictyostelium discoideum. In Development and Differentiation in the Cellular Slime Moulds, pp. 173-187. Edited by P. Cappuccinelli \& J. M. Ashworth. Amsterdam: Elsevier/ North-Holland.

STERNFEld, J. \& BonNer, J. T. (1977). Cell differentiation in Dictyostelium under submerged conditions. Proceedings of the National Academy of Sciences of the United States of America 74, 268-271.

STERNFElD, J. \& DAVID, C. N. (1979). Ammonia plus another factor are necessary for differentiation in submerged clumps of Dictyostelium. Journal of Cell Science 38, 181-191.

Strauss, A. J. L., Seegal, B. C., Hsu, K. C., Burkholder, P. M., NASTUK, W. L. \& OSSERman, K. E. (1960). Immunofluorescence demonstration of a muscle binding, complement fixing serum globulin fraction in Myasthenia gravis. Proceedings of the Society for Experimental Biology and Medicine 105, 184-191.

Sussman, M. \& OsBoRN, M. J. (1964). UDP-galactose polysaccharide transferase in the cellular slime mold, Dictyostelium discoideum: appearance and disappearance of activity during cell differentiation. Proceedings of the National Academy of Sciences of the United States of America 52, 81-87.

TAKEMoto, S., OKaMoto, K. \& TAKEUCHL, I. (1978) The effect of cyclic AMP on disaggregation-induced changes in activities of developmentally regulated enzymes in Dictyostelium discoideum. Biochemical and Biophysical Research Communications 80, 858-865.

TAKEUCHI, I. (1963). Immunochemical and immunohistochemical studies on the development of the cellular slime mold Dictyostelium mucoroides. Developmental Biology 8, 1-26.

TAKEUCHI, I. \& SAKAI, Y. (1971). Dedifferentiation of the disaggregated slug cell of the cellular slime mold Dictyostelium discoideum. Development, Growth and Differentiation 13, 201-210.

Takeuchi, I., Hayashi, M. \& TASaka, M. (1977). Cell differentiation and pattern formation in Dictyostelium. In Development and Differentiation in the Cellular Slime Moulds, pp. 1-16. Edited by P. Cappuccinelli \& J. M. Ashworth. Amsterdam: Elsevier/North Holland.

Takeuchi, I., OKamoto, K., Tasaka, M. \& TAKEMOTO, S. (1978). Regulation of cell differentiation in slime mold development. Botanical Magazine, Tokyo, Special Issue 1, 47-60.

TASAKA, M. \& TAKEUCHI, I. (1979). Sorting out behaviour of disaggregated cells in the absence of morphogenesis in Dictyostelium discoideum. Journal of Embryology and Experimental Morphology 49, 89-102.

Town, C. \& Gross, J. (1978). The role of cyclic nucleotides and cell agglomeration in post aggregative enzyme synthesis in Dictyostelium discoideum. Developmental Biology 63, 412-420.

Town, C. D., Gross, J. D. \& KAY, R. R. (1976). Cell differentiation without morphogenesis in Dictyostelium discoideum. Nature, London 262, 717-719.

Uchiyama, S., OKamoto, K. \& Takeuchi, I. (1979). Repression of rRNA synthesis induced by disaggregation in Dictyostelium discoideum. Biochimica et biophysica acta 562, 103-111.

Wilcox, D. K. \& Sussman, M. (1978). Spore differentiation by isolated Dictyostelium discoideum cells, triggered by prior cell contact. Differentiation 11, 125-131. 